\title{
Income Diversification and Bank Stability: Evidence from India
}

\author{
Navneet Kaur ${ }^{1}$, Santosh Srivatsav ${ }^{2}$, Nemiraja Jadiyappa ${ }^{3}$, Parneet kaur ${ }^{4}$
}

Modern portfolio theory claims that diversification into non-correlated or negatively correlated activities reduces the overall risk of a portfolio. Considering the total income of a bank as a portfolio of interest income and non-interest income, this paper investigates how the variability of interest income and non- interest income, and covariance between interest income and noninterest income influence the various risk factors of banks. We set out a study in the Indian context. We have extracted data for the period 2005-2017 and employed an extended version of Ridge, Lasso and Elastics Net regression to take care of multi-collinearly in our data. We have considered 10-fold cross-validation techniques to get optimal values of tuning parameters for Ridge, Lasso, and Elastics Net regression (which is a convex combination of ridge and the LASSO). We have compared different regression techniques by comparing RMSE and $R^{2}$. We observe that noninterest income is positively correlated with interest income in the Indian context, but it does stabilize variance, idiosyncratic risk \& market risk (Beta) of Indian Banks.

Key Words: Income diversification; idiosyncratic risk; emerging economies; Ridge/Lasso/ Elastics net regression

JEL Classifications: G20, G21, G28

\section{Introduction}

Interest income is considered as the main source of revenue for banks. However, banks do diversify their business into non-interest income category to enhance their income and to reduce the overall risk. This study explores the same in Indian context which is one of the largest bank-based economies. In addition to interest income, Indian banks also make money from activities like a commission, brokerage, dividends, trading (treasury) and so on. Broadly incomes of banks can be categorized into fund-based income and fee-based income. Figure 1 graphically represents the same. Income sources like trading (Treasury) based on stock markets are more rewarding, but at the same time, these sources are riskier than income sources such as commission or brokerage.

\footnotetext{
${ }^{1}$ Assistant professor, Institute of Management Technology, Nagpur, India, Email: navneetvir@gmail.com (ph: 7986227280)

${ }^{2}$ Assistant professor, Institute of Management Technology, Nagpur, India

${ }^{3}$ Assistant professor, Institute of Management Technology, Nagpur, India

${ }^{4}$ Assistant professor, Punjabi university Patiala, School of Management Studies, India
} 
Our study suggests that Indian Banks are not so diversified. For instance, the non-interest income of Indian banks ranges from $2 \%$ to $37.7 \%$. Interestingly, in comparison to Indian private sector banks whose share of non-interest income is in the range of $5.45 \%$ to $37.73 \%$ (average $14.62 \%$ ), Indian public sector banks are even less diversified whose non-interest income accounts for mere $2 \%$ to $24.8 \%$ ( average $11.12 \%$ ) of their total revenue. On the contrary, the proportion of noninterest income for US banks ranges from $2.2 \%$ to $98.4 \%$ (average 23.9 ).

Deyoung and Rice (2004) noted that "rebalancing bank income away from interest income and toward noninterest activities and fee income would make banking companies less risky." They further argue that reducing "interest income — with its sensitivity to the unpredictable movements in interest rates and the business cycle - would reduce the volatility of bank income and expanding into nontraditional fee-based activities would yield risk-reducing benefits of diversification".

In sync with the above, modern portfolio theory also suggests that the total risk of the portfolio can be reduced by diversifying the portfolio into relatively unrelated activities. It is important to note that the variance of the portfolio not only depends on the individual variance of the components but also on the covariance among components of the portfolio. Thus, preferably a portfolio component should not be correlated or ideally should be negatively correlated.

Consequently, having non-interest income in the portfolio should reduce the overall variance of the banks if this non-interest income is negatively correlated with the interest income. Hence, this study investigates how the variance of interest income and non-interest income, and co-variances between interest income and non-interest income impact the return, total risk, idiosyncratic and market risk of banks in the Indian context

Our empirical evidence suggests that even though non-interest income is correlated with interest income, still non-interest income can stabilize the total variance and idiosyncratic risk of banks significantly. Moreover, non-interest income is also helping in stabilizing the market beta of banks.

Figure 1: Sources of Bank Income in India

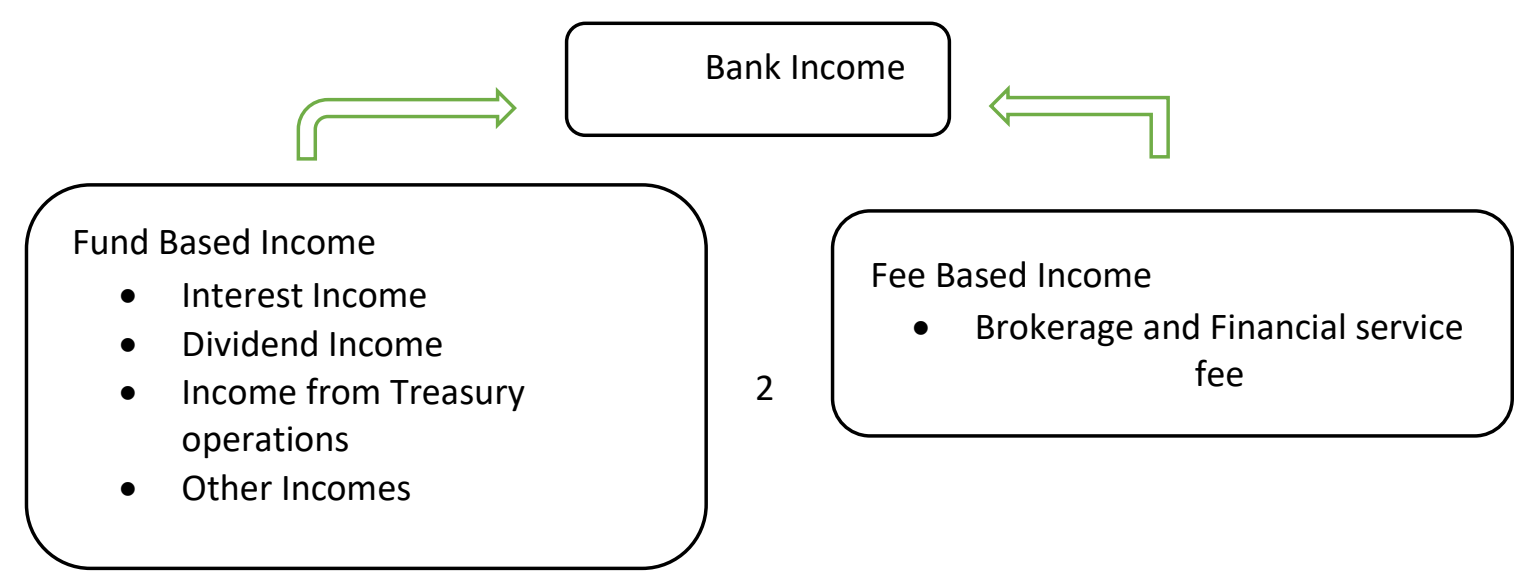




\section{The Banking system ${ }^{5}$}

The financial system of a country can be broadly categorized into two types namely, bank-based system and market-based system. Countries like Germany and Japan follow a bank-based system, whereas Anglo Saxon countries such as and the U.S. and U.K. follow a market-based system. In bank-based economy, the primary mode of financial resource mobilization is the banking sector. On the contrary, in a market-based economy equity markets play a dominant role in financial resource mobilization. Large bank-dominated financial systems of India play a crucial role for the corporate sector. Thus, by this classification, India is one of the leading bank-based economies. Indian banking sector consists of different type of institutions that cater to need of various stakeholders. In India small-scale credit cooperative banks, regional rural banks and local area banks also play a crucial role in the economy, in addition to large-scale Public sector banks (which accounts a whopping $73 \%$ of total assets of the entire banking sector as on March 2012), Private sector banks, and Private (Foreign banks) in India.

Two prevalent models of banking are commercial banking and investment banking. Universal banking is a combination of these two banking models in different proportions. There is a common consensus that universal banking will provide the largest economic benefits in a rapidly growing economy, such as India, in addition to diversification of business lines, innovations in risk management and market-based pricing of risks. Universal banking can efficiently work under three different regulatory environments.

a). Complete integration - most of the European countries follow this structure.

b). Parent bank (or a holding entity/bank) with non-bank operating subsidiaries- most of the Indian banks will come under this category.

\footnotetext{
${ }^{5}$ Banking structure in India - The way Forward (Discussion Paper: available at: https://rbidocs.rbi.org.in/rdocs/PublicationReport/Pdfs/DPBS27082013_F.pdf
} 
c). Parent holding company with the bank and non-bank affiliates - most of the U.S. Banks work under this model. Following Gram Leach Bliley (GLB) Act, Banks and non-bank affiliates operate under the Financial Holding Company.

The present structure of Indian banking sectors have few challenges regarding containing systematic risk. For example, parent banks in India have to infuse capital in the subsidiaries, and consequently, parent banks get directly impacted by the losses of the subsidiaries. Management of subsidiaries is a challenge for the parent bank's board. In case of liquidation of the parent bank, liquidation of subsidiaries become inevitable. So, the impact of income diversification on overall risk and return is even more important for Indian banks.

All scheduled commercial Banks in India are classified into Foreign Banks, Nationalised Banks, Private sector Banks, State Banks of India \& Its associates and small Finance banks. Nationalised Banks and State Bank of India \& Its associates comprises of total 69.9\% of Total Assets of Banking Industry and together with Private sector banks it is $93.9 \%$ in 2016. Nationalised Banks and State Bank of India \& Its associates comprises of total $68.8 \%$ of Total Assets of Banking Industry and together with Private sector banks it is $94.2 \%$ in 2017.

Table 1: Ownership wise Total Assets of Banks for the year 2016-17

\begin{tabular}{lllll} 
& & & & (Amount in million) \\
& $(\boldsymbol{\%})$ & $\mathbf{2 0 1 6}$ & $\mathbf{( \% )}$ & $\mathbf{2 0 1 7}$ \\
FOREIGN BANKS & 6.2 & 8144577 & 5.7 & 8095272 \\
NATIONALISED BANKS & 47.3 & 62064503 & 45.3 & 64124272 \\
PRIVATE SECTOR BANKS & 24.0 & 31467338 & 25.4 & 36015123 \\
STATE BANK OF INDIA \& ITS ASSOCIATES & 22.6 & 29616465 & 23.5 & 33231911 \\
SMALL FINANCE BANKS & 0.0 & & 0.1 & 119662 \\
& & & & \\
\hline ALL SCHEDULED COMMERCIAL BANKS & 100.0 & 131292882 & 100.0 & 141586239 \\
\end{tabular}

Source: Statistical Tables relating to Banks in India (RBI Website)

\section{Literature Review}


The literature on income diversification mainly focuses on accounting measures of performance and risks, which are captured through Return on Equity, Return on Asset and the standard deviation of these performance measures (to capture the risk). One of the earliest works by Wall (1987) didn't find any significant relationship between nonbanking activities and banking organization's risk. This study considered the data of US bank holding companies from 1976 to 1984 and concluded that non-banking activities might decrease risk. Similarly, another longitudinal study (from 1976 to 1985) by Kwast (1989) used portfolio theory to investigate the potential for diversification gains from bank's securities and non-securities activity and found some potential for diversification gain. In sync with this, Gallo et al. (1996) also found, specifically in the case of mutual fund activity for the period 1987 to 1994 for bank holding companies, that mutual fund activity increases the profitability of the banks and at the same time also moderated the systematic industry risk during the sample period.

Demsetz and Strahan (1997) argued in their paper that bigger bank holding firms are more diversified but riskier, and the reason for the same can be lower capital ratios and a large proportion of risky loans in a portfolio like commercial and industrial loans to assets. Similarly, Uzun and Webb (2007) considered quarterly data of 112 USA banks to study the impact of securitization on risk. They found that bank size is a significant determinant of securitization, and the extent of overall securitization is negatively related to the bank's capital ratio. In sync with this, Jiangli and Pritsker (2008) also found similar results for securitization. They noticed that mortgage securitization reduces insolvency risk but increases leverage and bank profitability. Similarly, Allen and Jagtiani (2000) examined the potential benefits of diversification from nonbank activities. Allen and Jagtiani (2000) concluded that securities underwriting if allowed, will expose the banks to greater market risk as well as interest rate risk. However, insurance activities have no significant impact on market risk, and it reduces the firm's exposure to market risk. In short, this study recommends that diversification will only make sense if the gains from synergies and demand effects are powerful enough to overcome the disadvantages of systematic risk exposure.

Stiroh (2004) assesses potential diversification benefits in the USA banking industry, and noted that at the aggregate level, declining volatility of net operating revenue reflects the reduced volatility of net interest income, rather than diversification benefits from noninterest income, which is quite volatile and highly correlated with net interest income. This study also found that 
greater reliance on noninterest income, particularly trading revenue, is associated with higher risk and lower profits. However, a recent study by Ahamed (2017), which has considered commercial Banks in India for the period 1998 to 2014, found that income diversification resulted in higher risk-adjusted returns for these banks. Similarly, another study in the Indian context from 2001 to 2009 by Pennathur et al., (2012) observed that fee-based income significantly reduced the risk for Indian banks.

Demirguc-Kunt and Huizinga (2010) found that noninterest income generating activities like trading activities increases the rate of return on asset, and offers risk diversification benefits at a very low level. On the other hand, non-deposit and wholesale funding lowers the rate of return on assets and some risk reduction at a low level of non-deposit funding. This study, based on 1334 banks from 101 countries provides evidence that overall, banking strategies that rely predominately on generating noninterest income or attracting non-deposit funding are very risky.

DeYoung and Roland (2001) constructed a degree-of-total-leverage framework to test whether and how shifts in product-mix affect earnings volatility for 472 commercial banks from the United States between 1988 and 1995. This framework, linked earnings volatility to revenue volatility, expense fixity, and product mix. This study also found that replacing traditional lending activities with fee-based activities - a trend which might get strengthened by financial modernization -- is associated with both higher revenue volatility and higher total leverage, subsequently, higher earnings volatility. An interesting study by DeJonghe (2010) has analyzed the relationship between diversification and the bank's ability to withstand a banking sector crash. In this study, systemic banking risk is measured as the tail beta, which equals the probability of a sharp decline in a bank's stock price conditional on a crash in a banking index. Subsequently, the impact of (the correlation between) interest income and the components of non-interest income on this risk measure is assessed. This paper concluded that smaller banks and better-capitalized banks are better able to withstand extremely adverse conditions.

There are handful of studies which considered market-based measures. For instance, Templeton and Severiens (1992) considered three market-based risk measures, i.e., the variance of shareholder returns, beta and the interest rate coefficient as the dependent variable and nonbank diversification as the independent variable. This longitudinal study (from 1979 to 1986 in the US) found that diversification results in a marginal decrease in risk but does not appear to effect 
systematic risk, i.e. beta. Similarly, Smith et al. (2003) considered data from 15 advanced countries, which are a member of the European Union, for the period 1994 to 1998. This study also found that increased reliance non-interest generating activities had stabilized profits. However, another study by Stiroh (2006) also considered market-based measures of risk (such as stock price variance, idiosyncratic risk and beta) for the United States bank holding companies from 1997 to 2004. This study observed that generating non-interest income does not lead to higher equity returns and are very risky as measured by return volatility and market beta.

To sum up, there are very few studies that focus on market-based return and risk measures, and second, studies are mainly in the context of U.S. and European market. Empirical evidence across different markets and different banking products are not at all conclusive. Furthermore, we note that there is hardly any study from emerging markets. Thus, this paper attempts to investigate that whether noninterest income adds to diversification benefits or not in the context of an emerging economy. We set our study in India, which is highly regulated and regulators restrict the entry of new players, to probe our research question.

\section{Data and Methodology}

We set our study in India. We have extracted weekly data of all Public and Private sector bank listed on National Stock Exchanges (NSE) during the period from 2005 to 2017. This resulted in 455 bank year observation for our study, out of which 182 are private bank year observation, and 254 are public sector bank-year observations. Stock market data is extracted from the NSE website, and accounting data is extracted from Reserve Bank of India (RBI) website. Variables are winsorized at the $1 \%$ level. NSE 50 index was considered for calculating the average return, total variance, and beta. The variables used are as follows:

\section{Dependent variables}

- Average return: an average of weekly returns are calculated for each bank for each year separately

- Total variance: variance of weekly returns are calculated for each year for each Bank separately

- Model variance: using equation $1, \mathrm{R}^{2}$ value is calculated for each year for each Bank and Model variance is the variance explained by $\mathrm{R}^{2}$ 
- Residual variance: Residual variance is the variance not explained by model (i.e., equation 1) which is $\left(1-\mathrm{R}^{2}\right)$

- Beta: Beta is calculated as the covariance of weekly returns with the variance of weekly market return

\section{Independent variable}

- Income diversification- Proportion of the interest income and the noninterest income out of the total income

\section{Control variables:}

- Log of assets to control for the size of the bank because larger banks are diversified geographywise, product-wise as well as customer-wise than smaller banks

- Equity/Assets - to control the capital structure because the leverage ratio magnifies the change in performance (Hamada, 1972) and market-based risk measures

Ferreira and Laux (2007) argue that the $\mathrm{R}^{2}$ of an equation gives the proportion of the variance explained by the market forces, i.e., systematic factors, therefore, $\left(1-\mathrm{R}^{2}\right)$ represent the idiosyncratic part of the overall risk. We measure stock returns as follows:

$$
\text { Stock_Returns }{ }_{i t}=\alpha_{i}+\beta_{i} \text { Market_Return } t+€_{i t} \quad \ldots \text { (1) }
$$

Here, Stock_Returns it $_{\text {is }}$ is the return of the $\mathrm{i}^{\text {th }}$ stock in the $\mathrm{t}^{\text {th }}$ week. We consider the NSE 50 index as the market index. We use OLS to estimate the coefficients of this model. This procedure gives the proportion of the total variance which is not explained by the market forces for each year, i.e., idiosyncratic volatility. In the second step, we use $\left(1-\mathrm{R}^{2}\right)$ from Eq (1) as the dependent variable and regress it on Bank diversification.

Table 1 summarizes the variables used. The study is based on 455 bank observations from 200517, with 21 Public sector banks and 14 Private sector banks. The mean annual return and the standard deviation of our samples are $0.44 \%$ and 0.91 respectively. Average returns for banks varies in the range of $-1.47 \%$ to $2.58 \%$ with the mean variance of 37.35 . Model variance percentage shows that on an average 10.78 of the variations in stock return can be explained by the market factors, and the rest is residual variance, which is specific for that particular bank, i.e. idiosyncratic risk $\left(1-\mathrm{R}^{2}\right)$. Mean beta value of 1.16 shows that if the market moves by $1 \%$, then the bank stock 
moves in the same direction by $1.16 \%$. These results are similar to results of Stiroh (2006), which has considered US bank-holding firms for the period 1997 to 2004 . The table 1 broadly indicates that Indian banks have reasonably diversified into non-interest generating activities. In fact, on an average, these banks are generating $12.5 \%$ of their income from non-interest activities varying from $2 \%$ to $38 \%$. Bank assets are in the range of 65.13 billion to 7200.00 billion (Indian Rupees), and equity percentage ranges from $0.07 \%$ to $7.4 \%$ with the mean equity percentage of $3.5 \%$. Kindly note that the reported the winsorized values in this table 1.

Table 1: Summary Statistics

\begin{tabular}{lrrrr}
\hline & Mean & SD & Min & \multicolumn{1}{c}{ Max } \\
Market Return Variables & & & & \\
Mean Annual return \% & 0.44 & 0.91 & -1.47 & 2.58 \\
Variance of Return\% & 37.35 & 22.03 & 10.61 & 127.76 \\
Model variance\% & 10.78 & 9.18 & 0.23 & 46.71 \\
Residual Variance\% & 25.39 & 15.57 & 4.81 & 105.36 \\
Market beta & 1.16 & 0.49 & 0.17 & 2.41 \\
& & & & \\
Bank Characteristics & & & & \\
Non interest share\% & 12.52 & 4.59 & 2.07 & 37.73 \\
Log(Assets) & 5.98 & 0.47 & 4.81 & 6.86 \\
Assets(Rs, billion) & 1594.12 & 1597.18 & 65.13 & 7200.00 \\
Equity/Assets (\%) & 3.57 & 2.66 & 0.07 & 7.41 \\
\hline
\end{tabular}

Following Stiroh (2006), we have followed the portfolio approach for income diversification. Table 2 presents the results of Bank Return Regression. To avoid multicollinearity, the proportion of non-interest income was only considered. Model M1 is regressing proportion of noninterest income on annual bank return (i.e., an average of weekly stock returns for each year and each of the banks), and we note that even though the coefficient of interest proportion is positive, but the constant is negative and insignificant with a very low $\mathrm{R}^{2}$. We control for the asset size and leverage (equity/ Asset) in M2 and note that the constant turns positive and significant with a minor improvement in $R^{2}$. With year effect in $M 3, R^{2}$ has significantly improved from 0.04 to 0.32 , but coefficients turned insignificant. In brief, the larger the bank in asset size, lower the average market return, however, when controlled for the year effects, this relation does not exist.

\section{Empirical Results}




\section{Table 2: Bank Return Regression}

We have operationalized the expected return as follows: $\left(E(R)=\alpha+E\left(R_{I}\right) \cdot w+E\left(R_{N I}\right) \cdot(1-w)\right.$ Where $E(R)$ is the expected return, and it is a function of expected return on interest Income $\left(E\left(R_{I}\right)\right)$ multiplied by the proportion of interest income in total income plus Expected return of non-interest income $\left(E\left(R_{N I}\right)\right)$ multiplied by the proportion of non-interest income in total income. Following prior studies, we have incorporated the control variables for size, i.e. the log of assets and capital structure calculated as (Equity/Assets), i.e. paid-up capital plus reserves divided by Total Assets.

\begin{tabular}{lccc}
\hline Bank Characteristics & M1 & M2 & M3 \\
Non interest share & & & \\
& $0.057 * *$ & $0.044^{*}$ & 0.034 \\
Log(Assets) & $(0.02)$ & $(0.02)$ & $(0.02)$ \\
& & $-0.407 *$ & -0.253 \\
Equity/Assets & $(-0.18)$ & $(-0.22)$ \\
& & -0.04 & -0.057 \\
Constant & -0.192 & $(-0.04)$ & $(-0.04)$ \\
& $(-0.25)$ & $(1.06)$ & 1.594 \\
& & & $(1.12)$ \\
Obs. & 455 & 455 & 455 \\
Winsorized & Yes & Yes & Yes \\
Year Effect & No & No & Yes \\
$\mathrm{R}^{2}$ & 0.02 & 0.04 & 0.32 \\
$* * *$ implies significance at the $1 \%, 5 \%$ and $10 \%$ respectively) & &
\end{tabular}

It is important to note, in Table 3, that our explanatory variables, such as quadratic terms and interaction variables, are highly correlated. Hence, using linear regression over this equation will give weak results. Multicollinearity leads to the problem of overfitting and numerical instability. Thus, we run the models for Ridge, Lasso and Elastics Net regression to avoid the problem of multicollinearity and overfitting. We have used 10-fold cross-validation techniques to get optimal value of tuning parameters in our Ridge, Lasso and Elastics Net (RLEN) regression model (which is a convex combination of Ridge and the Lasso). The evaluation of different regression methods has been done by comparing RMSE and $\mathrm{R}^{2}$.

Ridge, Lasso, and Elastic Net Regression are the techniques for analyzing multiple regression data with multicollinearity. When multicollinearity is there, ordinary least squares (OLS) estimates are unbiased, but their variances are large, so OLS models are not appropriate. However, by adding a degree of bias to the regression estimates, RLEN regression model reduces the standard errors. 
Prior studies noted that RLEN regression techniques give estimates that are more reliable (Khalaf and Shukur 2005, Muniz and Kibria 2009, Tibshirani 1996).

Lasso regression is a type of linear regression that uses shrinkage. Shrinkage is where data values are shrunk towards a central point, like the mean. The Lasso procedure encourages simple, sparse models (i.e., models with fewer parameters). This particular type of regression is well-suited for models showing high levels of multicollinearity. The Elastic Net regression is a regularized regression method that linearly combines the $\mathrm{L}_{1}$ and $\mathrm{L}_{2}$ penalties of the lasso and ridge methods (Hans, 2011). Table 3 and 4 present the results for determinants of total variance and residual variance.

Table 3 \& Table 4 report the results in 4 parts as follows: Ridge Regression (in Part 1), Lasso Regression (in Part 2), Elastics Net regression (in Part 3) and Regression results with suppressed constant (in Part 4).

\section{Table 3: Variance of Stock returns and Income Diversification}

$\sigma^{2}{ }_{R}=\sigma_{I}^{2} \cdot w^{2}+\sigma^{2}{ }_{N I}(1-w)^{2}+\operatorname{Cov}(I, N I) \cdot 2 \cdot w \cdot(1-w)$, Where, $\sigma^{2}{ }_{R}=$ expected variance of stock returns, $\sigma_{I}^{2} \cdot w^{2}=$ square of weight (proportion) of net interest income multiplied by variance of interest income, $\sigma^{2}{ }_{N I}(1-w)^{2}=$ square of weight (proportion) of net non-interest income multiplied by variance of noninterest income, $\operatorname{Cov}(I, N I) \cdot 2 \cdot w \cdot(1-w)=$ covariance of proportion of interest income and non-interest income multiplied by proportion of interest income and proportion of non-interest income, multiplied by 2. Log (Asset) is a log of Assets, and Equity/Assets is the paid-up capital plus reserves divided by Total Assets.

Part1: Ridge Regression output

\begin{tabular}{lccc}
\hline & M1 & M2 & M3 \\
Bank Characteristics & & & \\
Non interest proportion & & & \\
(1-Non interest proportion) $^{2}$ & $-239.75^{*}$ & $-328.15^{* *}$ & $\mathbf{- 3 4 * * *}$ \\
2(interest prop*Noninterest prop) & $-20.86^{* *}$ & $-23^{* *}$ & $\mathbf{1 1 * * *}$ \\
Log(Assets) & $53.594^{*}$ & $76^{*}$ & $\mathbf{2 . 9 9 * *}$ \\
Equity/Assets & & $-18.84^{*}$ & $\mathbf{- 8 . 6 3 * *}$ \\
& & $1.20 *$ & $\mathbf{- 0 . 0 7 *}$ \\
\hline Obs. & & & \\
Winsorized & 455 & 455 & $\mathbf{4 5 5}$ \\
Year Effect & Yes & Yes & Yes \\
R $^{2}$ & No & No & Yes \\
RMSE & 0.02 & 0.11 & $\mathbf{0 . 3 9}$ \\
\hline
\end{tabular}


Part 2: Lasso Regression Output

\begin{tabular}{llll}
\hline $\begin{array}{l}\text { Bank Characteristics } \\
\text { (1-Non interest proportion) }^{2}\end{array}$ & M1 & M2 & M3 \\
$\begin{array}{l}\text { Non interest proportion } \\
\text { 2(interest prop*Noninterest prop) }\end{array}$ & $\ldots \ldots$ & $18.53^{* *}$ & $4.23^{* *}$ \\
Log(Assets) & $\ldots \ldots$ & $-415.63^{* * *}$ & $-3.95^{* *}$ \\
Equity/Assets & $24^{*}$ & $148^{*}$ & $\ldots$. \\
& & $-19.98^{* * *}$ & $-8.73^{* * *}$ \\
& & $1.34^{* *}$ & $\ldots$ \\
Obs. & 455 & 455 & 455 \\
Winsorized & Yes & Yes & Yes \\
Year Effect & No & No & Yes \\
$\mathrm{R}^{2}$ & 0.027 & 0.13 & 0.42 \\
RMSE & 27.82 & 26.6 & 22.11 \\
\hline
\end{tabular}

Table 3: Variance of Stock returns and Income Diversification (contd.) Part 3: (Elastics Net Regression output)

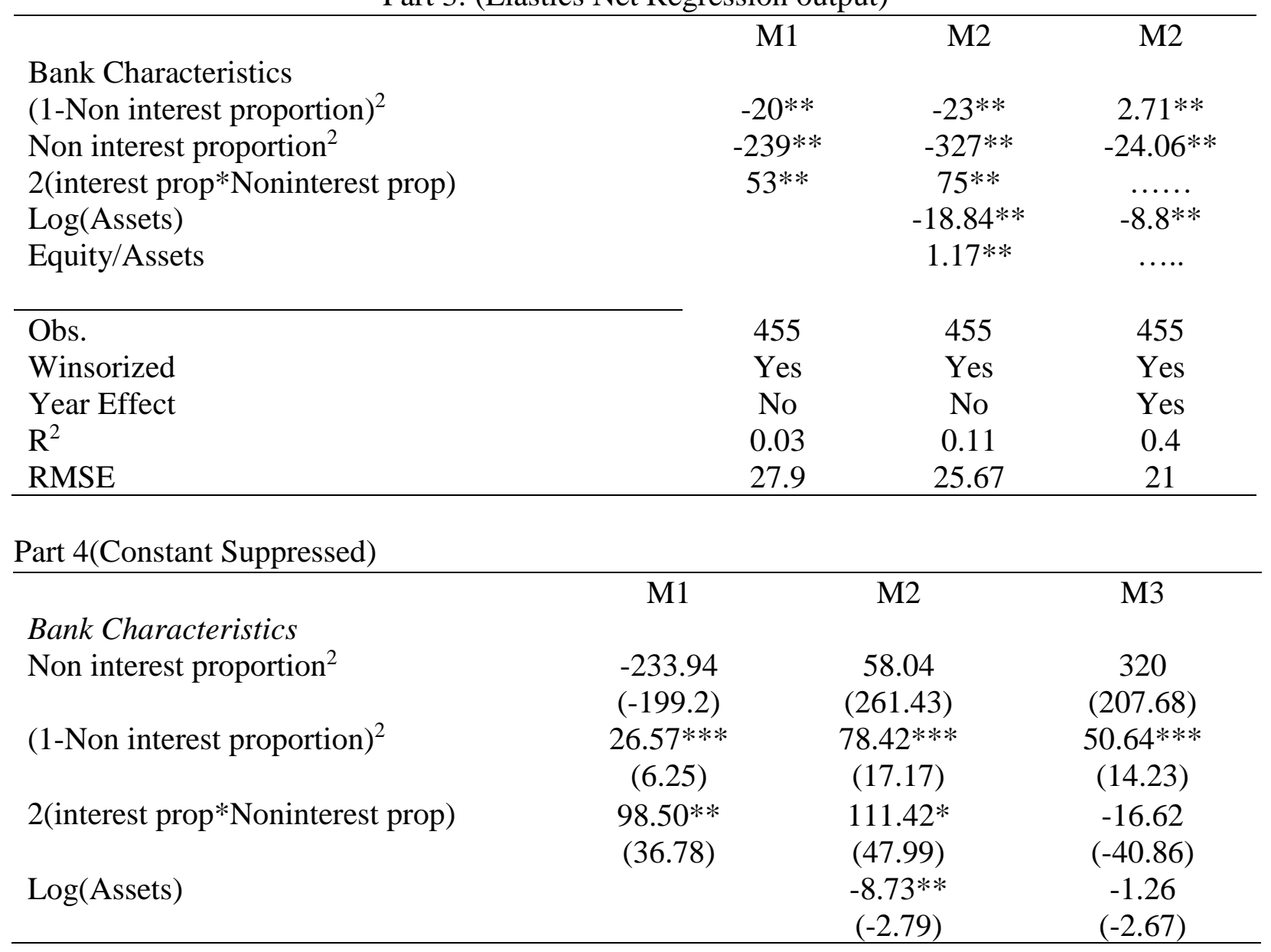




\begin{tabular}{lccc}
\hline Equity/Assets & & $1.121^{*}$ & 0.001 \\
& & $(0.52)$ & $(0.46)$ \\
\hline Obs. & 455 & 455 & 455 \\
Winsorized & Yes & Yes & Yes \\
Year Effect & No & No & Yes \\
$\mathrm{R}^{2}$ & 0.74 & 0.76 & 0.86 \\
\hline$(* * *, * * *$ implies significance at the $1 \%, 5 \%$ and $10 \%$ respectively) & &
\end{tabular}

M1 in Table 3 (Part 1) shows the contribution of interest income variance, non-interest income variance and covariance of interest income and non-interest income variance to the total variance of stock returns. Output in Table 3 (Part 1), M1 shows that covariance of interest income and noninterest income is adding significantly to the total variance. However, the coefficient for noninterest income and interest income variance is negative but insignificant. When controlled for size effect and the leverage effect in M2, the coefficient of variance for non-interest income and covariance's increases in size from -239.75 to -328.15 and 53.59 to 76 respectively. In M3, when controlled for year effect it is the only variance for interest income, and the covariance coefficient that adds to total variance significantly and non-interest income is reducing the variance. As Table 3 shows, when controlled for year, size and leverage are negatively related to bank variance in Model 3.

Part 2 shows the regression results with Lasso regression output. Where M1 is dropping the variables with an $R^{2}$ of 0.02 and $M 2$ with no year effect, have an $R^{2}$ of 0.13 . M3 report the $R^{2}$ of 0.42 but is dropping the covariance term. Part 3 reports the result of Elastic Net regression, where $\mathrm{M} 1$ is not dropping the variables with an $\mathrm{R}^{2}$ of 0.03 , and $\mathrm{M} 2$ with no year effect have $\mathrm{R}^{2}$ of 0.11 . $\mathrm{M} 3$ reports the $\mathrm{R}^{2}$ of 0.41 but is dropping the covariance term.

In part 4, we have used the traditional method of dealing with multicollinearity by suppressing the

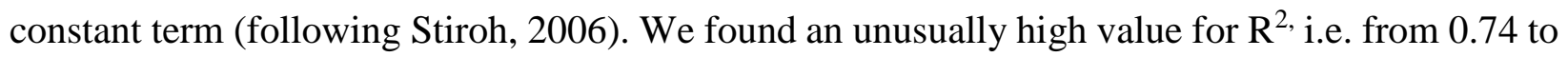
0.86. If we compare the four types of regression output, the ridge regression gives an efficient result, keeping all the variables and putting $\mathrm{R}^{2}$ 0.39 and RMSE 22.2 (Part 1, M3).

M1 in Table 4 shows the contribution of interest income variance, non-interest income variance, and covariance of interest income, and non-interest income variance to residual variance (i.e., 1$\mathrm{R}^{2}$ from Eq. 1) of stock returns. In Table 4, M1 shows that the covariance of interest income and 
non-interest income is adding significantly to residual variance. The coefficient for noninterest income variance and interest income variance are negative and significant. When controlled for the size effects and the leverage effects in M2, the coefficients of variance of non-interest income and covariance increases in size from -148 to -226 and 27 to 45 respectively. In M3, when controlled for year effect, then the variance for non-interest income is negatively associated with residual variance significantly. Both interest income variance and covariance are positively associated with residual variance. In table 4, M3 shows, when controlled for year, size and leverage are negatively associated with the bank residual variance with an $\mathrm{R}^{2}$ of 0.30 .

In Table 2, Part 2 shows the result for Lasso Regression. M1 and M3 dropped the variables, and $\mathrm{M} 2$ has a $\mathrm{R}^{2}$ of 0.18 . Part 3 shows the result for Elastic Net regression, M1 and M3 dropped the variables and $\mathrm{M} 2$ has a $\mathrm{R}^{2}$ of 0.19 . In part 4, with suppressed constant, we found an unusually high value for $\mathrm{R}^{2}$, i.e. from 0.72 to 0.82 . If we compare the three types of regression output, the ridge regression gives the most efficient result putting R square 0.3 and RMSE 17.8 (Part 1, M3)

\section{Table 4: Idiosyncratic risk of Banks and Income Diversification}

$\sigma_{R}^{2}=\sigma_{I}^{2} \cdot w^{2}+\sigma_{N I}^{2}(1-w)^{2}+\operatorname{Cov}(I, N I) \cdot 2 \cdot w \cdot(1-w)$, Where, $\sigma_{R}^{2}=$ expected residual variance $\left(1-R^{2}\right)$ of stock returns, $\sigma_{I}^{2} \cdot w^{2}=$ square of weight (proportion) of net interest income multiplied by variance of interest income, $\sigma_{N I}^{2}(1-w)^{2}=$ square of weight (proportion) of net non-interest income multiplied by variance of non-interest income, Cov $(I, N I) \cdot 2 \cdot w \cdot(1-w)=$ covariance of proportion of Interest income and non-interest income multiplied by proportion of interest income and proportion of non-interest income, multiplied by 2. Log (Asset) is a log of Assets, and Equity/Assets is the paid-up capital plus reserves divided by Total Assets.

Part 1: Ridge Regression Output

M1 M2 M3

Bank Characteristics

Non interest proportion ${ }^{2}$

$-148 * * \quad-226 * * \quad \mathbf{8 1 * *}$

$(1-\text { Non interest proportion })^{2}$

$-13 * *$

$-14 * *$

$12 * *$

2(interest prop*Noninterest prop)

$27 *$

$45 * *$

$0.77 * *$

Log(Assets)

$-18^{*}$

$-10.49 *$

Equity/Assets

$0.88 *$

$-0.11 * *$

Obs.
Winsorized
Year Effect
$\mathrm{R}^{2}$
RMSE

455

Yes

No

455

455

Yes

0.019

No

Yes

21.82

0.19

Yes

RMSE

20.12

0.3

17.8 
Part 2: (Lasso Regression Output)

M1 M2 M3

Bank Characteristics

Non interest proportion ${ }^{2}$

${\text { (1-Non interest proportion })^{2}}^{2}$

2(interest prop*Noninterest prop)

Log(Assets)

Equity/Assets

$\begin{array}{lll}\ldots \ldots & -312.87^{* *} & -63 * * \\ \ldots & 4.62^{* *} & \ldots \\ \ldots \ldots & 89.34^{* *} & \ldots . \\ & -19.5^{* *} & -11.37 * * \\ & 1.05^{* *} & \ldots .\end{array}$

Obs.

455

455

455

Winsorized

Year Effect

Yes

$\mathrm{R}^{2}$

No

RMSE

0.014

Yes

No

Yes

$21.8 \quad 20.25$

0.18

Yes

0.29

20.25

19

Part3: Elastics Net Regression Output

M1 M2 M3

Bank Characteristics

Non interest proportion ${ }^{2}$

${\text { (1-Non interest proportion })^{2}}^{2}$

2(interest prop*Noninterest prop)

Log(Assets)

Equity/Assets

$\begin{array}{lll}\ldots \ldots & -226.89 * * & -80.78 * * * \\ \ldots . & -14.53 * * & 0.03 * * \\ \ldots \ldots & 45.00^{* *} & \ldots \ldots \\ & -18.31 * * & -11.21 * * \\ & 0.88 * & \ldots \ldots\end{array}$

Winsorized
Year Effect
$\mathrm{R}^{2}$

RMSE

Yes
No
0.014
24.19

Yes

No

Yes

Yes

0.19

0.3

20.12

18.23

Part 4: Constant Suppressed

\begin{tabular}{lccc}
\hline & M1 & M2 & M3 \\
Bank Characteristics & & & 100.41 \\
Non interest proportion $^{2}$ & -75.63 & $(174.55)$ & $(161.77)$ \\
& $(-140.41)$ & $77.37 * * *$ & $62.61^{* * *}$ \\
(1-Non interest proportion) $^{2}$ & $19.36^{* * *}$ & $(11.60)$ & $(11.20)$ \\
& $(4.41)$ & $97.37 * *$ & 22.00 \\
2(interest prop*Noninterest prop) & $55.47^{*}$ & $(32.19)$ & $(31.97)$ \\
& $(25.95)$ & & \\
\hline
\end{tabular}


$\log$ (Assets)

Equity/Assets
$-10.15 * * *$

$(-1.89)$

$1.059 * *$

$(0.35)$
$-3.89$

0.01

$(0.37)$

455

Yes

Yes

0.82

Obs.

455

455

Yes

No

No

0.72

0.76

$(* * *, * *, *$ implies significance at the $1 \%, 5 \%$ and $10 \%$ respectively)

Table 5 compiles the results for beta regression. Non-interest income share negatively contributes to systematic risk (Beta) at banks having noninterest income in the income stream. This plays a stabilizing effect even after controlling for size and leverage. M2 shows that bigger the bank size, more will be the market variance as clear with signs and the coefficient for a log of asset variable on Beta.

\section{Table 5: Beta of Bank and Income Diversification}

We have operationalized the expected return as follows: $\beta=\alpha+N I(1-w)$, Where $\beta$ is Beta, multiplied by the proportion of non-interest income in total income. Following prior studies, we have incorporated the control variables for size, i.e. the log of assets and capital structure calculated as (Equity/Assets), i.e. paid-up capital plus reserves divided by Total Assets

\begin{tabular}{lcc}
\hline & M1 & M2 \\
Bank Characteristics & & \\
Non interest share & $-0.05 * * *$ & $-0.03 * * *$ \\
& $(-0.01)$ & $(-0.01)$ \\
Log(Assets) & & $0.62 * * *$ \\
& & $(0.06)$ \\
Equity/Assets & & $-0.03 *$ \\
& & $(-0.01)$ \\
Constant & $1.79 * * *$ & $-2.04 * * *$ \\
& $(0.1)$ & $(-0.37)$ \\
\hline Obs. & 455 & 455 \\
Winsorized & Yes & Yes \\
Year Effect & No & No \\
$\mathrm{R}^{2}$ & 0.04 & 0.23 \\
\hline \multicolumn{2}{c}{$(* * *, * * *$ implies significance at the $1 \%, 5 \%$ and $10 \%$ respectively) }
\end{tabular}




\section{Discussion}

Prior studies noted that there is a mix of evidence not only from different markets but also for different banking products (Saunders and Walter, 1994). The story is broadly similar in the Indian context. As we mentioned earlier, Indian banks operate under strict regulatory guidelines from the Reserve Bank of India. So, Indian banking sector is characterized by entry restriction, priority sector lending, and so on. It is worth remembering that we noted that most Indian banks are less diversified with a significant low share of non-interest income share in comparison to banks from the United States.

We find that unlike U.S. Banks, non-interest income is stabilizing the variance, idiosyncratic risk and Beta of banks with no significant impact on returns. One potential reason can be the diversification level of Indian Banks. As noted by Stiroh (2006) that banks do benefit from diversification when noninterest income share is in the range of $18 \%$ to $27 \%$. It is worth noting that banks from the United States are already well diversified and their average level is much higher than this range. So, they fail to create value, but Indian banks with a low level of diversification can create value by diversifying their source of income. This confirms the corporate finance literature which says that a moderate level of diversification creates value, but overdiversification destroys value.

Furthermore, we also note that based on the aggregate proportion of non-interest income, the contribution of non-interest income is positively adding to a market return of a bank's stock. However, after adding a year dummy, the contribution becomes insignificant, but still, the coefficient remains positive. Thus, it can be concluded from our study that non-interest income is playing a significant and stabilizing role for systematic risk of Indian banks. When markets are becoming more interlinked, then each unit of systematic risk become potentially more costly (Allen and Jagtiani 2000).

To sum up, our overall findings are in sync with earlier studies (such as Ahamed 2017; Pennathur et al., 2012). Findings from our robust statistical techniques convey that ensuring non-interest income helps the banking sector to stabilize. This study can be extended further by linking not only income-diversification with variance, but also the composition of the loan portfolio, i.e. deposit vis-a-vis non-deposit funding also with variance, as risk and return does not only depend 
on the quantity of loan but also on the quality of loan that is best captured by risk-weighted assets, credit risk, market risk and operational risk.

\section{References}

Ahamed, M.M., 2017. Asset quality, non-interest income, and bank profitability: Evidence from Indian banks. Economic Modelling, 63, pp.1-14.

Allen, L. and Jagtiani, J., 2000. The risk effects of combining banking, securities, and insurance activities. Journal of Economics and Business, 52(6), pp.485-497.

De Jonghe, O., 2010. Back to the basics in banking? A micro-analysis of banking system stability. Journal of financial intermediation, 19(3), pp.387-417.

Demirgüç-Kunt, A. and Huizinga, H., 2010. Bank activity and funding strategies: The impact on risk and returns. Journal of Financial Economics, 98(3), pp.626-650

Demsetz, R.S. and Strahan, P.E., 1997. Diversification, size, and risk at bank holding companies. Journal of money, credit, and banking, pp.300-313.

DeYoung, R. and Rice, T., 2004. How do banks make money? The fallacies of fee income. Economic Perspectives-Federal Reserve Bank of Chicago, 28(4), p.34.

DeYoung, R. and Roland, K.P., 2001. Product mix and earnings volatility at commercial banks: Evidence from a degree of total leverage model. Journal of Financial Intermediation, 10(1), pp.54-84.

Ferreira, M.A. and Laux, P.A., 2007. Corporate governance, idiosyncratic risk, and information flow. The Journal of Finance, 62(2), pp.951-989.

Gallo, J.G., Apilado, V.P. and Kolari, J.W., 1996. Commercial bank mutual fund activities: Implications for bank risk and profitability. Journal of Banking \& Finance, 20(10), pp.17751791.

Hamada, R.S., 1972. The effect of the firm's capital structure on the systematic risk of common stocks. The Journal of Finance, 27(2), pp.435-452.

Hans, C., 2011. Elastic net regression modeling with the orthant normal prior. Journal of the American Statistical Association, 106(496), pp.1383-1393

Jiangli, W. and Pritsker, M., 2008. The impacts of securitization on US bank holding companies.

Khalaf, G. and Shukur, G., 2005. Choosing Ridge Parameter for Regression Problems. Communications in Statistics-Theory and Methods, 34(5), pp.1177-1182. 
Kwast, M.L., 1989. The impact of underwriting and dealing on bank returns and risks. Journal of Banking \& Finance, 13(1), pp.101-125.

McDonald, G.C., 2009. Ridge regression. Wiley Interdisciplinary Reviews: Computational Statistics, 1(1), pp.93-100.

Muniz, G. and Kibria, B.G., 2009. On some ridge regression estimators: An empirical comparisons. Communications in Statistics—Simulation and Computation®, 38(3), pp.621630 .

Pennathur, A.K., Subrahmanyam, V. and Vishwasrao, S., 2012. Income diversification and risk: Does ownership matter? An empirical examination of Indian banks. Journal of Banking \& Finance, 36(8), pp.2203-2215.

Saunders, A. and Walter, I., 1994. Universal banking in the United States: What could we gain? What could we lose? Oxford University Press.

Smith, R., Staikouras, C. and Wood, G., 2003. Non-interest income and total income stability.

Stiroh, K.J., 2004. Diversification in banking: Is noninterest income the answer? Journal of Money, Credit, and Banking, 36(5), pp.853-882.

Stiroh, K.J., 2006. A portfolio view of banking with interest and noninterest activities. Journal of Money, Credit, and Banking, 38(5), pp.1351-1361.

Templeton, W.K. and Severiens, J.T., 1992. The effect of nonbank diversification on bank holding company risk. Quarterly Journal of Business and Economics, pp.3-17.

Tibshirani, R., 1996. Regression shrinkage and selection via the lasso. Journal of the Royal Statistical Society. Series B (Methodological), pp.267-288.

Uzun, H. and Webb, E., 2007. Securitization and risk: empirical evidence on US banks. The Journal of Risk Finance, 8(1), pp.11-23.

Wall, L.D., 1987. Has bank holding companies' diversification affected their risk of failure? Journal of Economics and Business, 39(4), pp.313-326. 